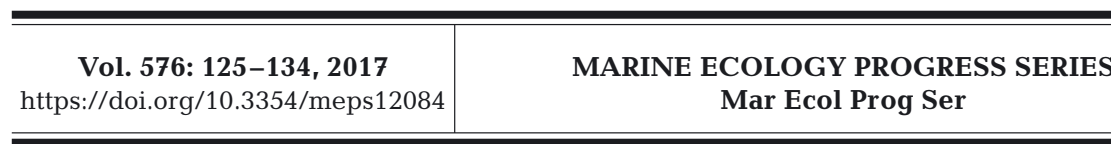

Contribution to the Theme Section

'Response of nearshore ecosystems to the Deepwater Horizon oil spill'

\title{
Avoidance of oil contaminated sediments by estuarine fishes
}

\author{
Charles W. Martin* \\ Department of Oceanography Coastal Sciences, Louisiana State University, Baton Rouge, LA 70803, USA \\ Present address: University of Florida Institute of Food and Agricultural Sciences Nature Coast Biological Station, \\ Cedar Key, FL 32625, USA
}

\begin{abstract}
The explosion of the Deepwater Horizon drilling platform and subsequent discharge of hydrocarbons into the Gulf of Mexico is the largest oil spill that has affected US waters. To date, studies of ecological effects on coastal fishes have produced complex results. While laboratory studies indicate that oil has widespread, pervasive impacts on fish physiology, field assessments often document few impacts to fish abundance and biomass following a spill. The dichotomy of such results suggests that negative individual-level effects do not translate to population/community-level consequences. One explanation for this discrepancy is that mobile organisms may avoid oil, which was very patchily distributed. Here, I present the results of experiments using 3 estuarine fishes (gulf killifish Fundulus grandis, sailfin molly Poecilia latipinna, and sheepshead minnow Cyprinodon variegatus) to determine whether behavioral avoidance occurs at a range of concentrations $\left(0,10,20\right.$, and $40 \mathrm{ml}$ oil $\mathrm{l}^{-1}$ of sediment) and weathering (fresh or weathered oil) scenarios. All 3 species avoided medium $(35,18,10 \%$ of trial time, respectively) and high concentrations of fresh oil $(30,20$, and $15 \%$, respectively), while time spent over contaminated sediments at low concentrations of fresh oil was higher $(30,40$, and $40 \%$, respectively). Weathered crude elicited no significant avoidance behavior, with fish occupying between 40 and $60 \%$ of the trial period over these sediments, regardless of concentration. This research highlights the heretofore unrecognized role of behavior in fish resilience, as well as the need for future studies to incorporate ecologically relevant weathering rates. Such results are critical to the successful management of motile resources, such as estuarine fishes, in response to anthropogenic disasters such as oil spills.
\end{abstract}

KEY WORDS: Salt marsh · Gulf of Mexico - Fish ecology · Experiment · Avoidance behavior · Oil contamination $\cdot$ Oil spill $\cdot$ Deepwater Horizon $\cdot$ Macondo

\section{INTRODUCTION}

The April 2010 explosion and sinking of the Deepwater Horizon (DWH) drilling platform off the coast of Louisiana (USA) in the Mississippi Canyon Block 252 (MC252) released about 5 million barrels of 'sweet' Louisiana crude oil into surrounding waters as it flowed unabated for $87 \mathrm{~d}$ (Crone \& Tolstoy 2010). It has been recognized as the largest marine oil spill in US history, equivalent to 20 times the areal coverage of the 'Exxon Valdez' disaster (Turner et al. 2014a). Prevailing meteorological conditions led to the subsequent oiling of many coastal wetlands rang-

*Corresponding author: martin.charles.w@gmail.com

${ }^{\S}$ Advance View was available online March 8, 2017; subsequently updated May 2, 2017 ing from Louisiana to the Florida Panhandle in the northern Gulf of Mexico (GoM), with a total of $1773 \mathrm{~km}$ of affected shoreline (Michel et al. 2013).

The oil released during this event was a complex mixture containing tens of thousands of different chemical constituents, ranging from lightweight aromatic chemicals that volatilize and degrade quickly, to larger carbon chains that are resilient to weathering. As oil was distributed into inshore coastal areas, numerous processes (including photooxidation, evaporation, emulsification, microbial activity, dissolution, and adsorption to sediment particles) led to a much different chemical mixture than that found closer to

( ) The author 2017. Open Access under Creative Commons by Attribution Licence. Use, distribution and reproduction are unrestricted. Authors and original publication must be credited.

Publisher: Inter-Research · www.int-res.com 
the offshore source (Mendelssohn et al. 2012). In general, oil reaching inshore areas was heavily weathered, and this altered crude was less toxic with fewer water-soluble compounds (Reddy et al. 2012).

The various habitats (marshes, mangroves, sandy beaches, and seagrass beds) in the affected area provide a variety of important ecosystem services, including buffering coastlines from high-energy storm events, improving water quality and clarity, and providing food and refuge for many commercially and recreationally important organisms (Baltz et al. 1993, Peterson \& Turner 1994, Rozas et al. 2013). Spartina alterniflora in salt marshes is the most abundant emergent plant species in coastal Louisiana, despite areal coverage decreasing from historical levels due to a variety of proposed factors, including subsidence, canalization, eutrophication, shunting of sediment supply, urbanization, and environmental toxins such as oil (Silliman et al. 2012). Salt marshes were the most frequently oiled habitat (45\%) during the DWH spill, and remedial activities occurred on $<9 \%$ of the affected area (Michel et al. 2013). The resilience of these habitats is critical to the persistence of resident fishes that inhabit these marshes, as well as the energy that is diverted to pelagic food webs (Peterson \& Turner 1994, McCann et al. in press). The vulnerability of estuarine ecosystems and their fauna to oil released from DWH has been illustrated by numerous studies (e.g. Silliman et al. 2012, Fodrie et al. 2014, Rozas et al. 2014, Pezeshki \& Delaune2015).

While the full scope of the ecological impacts of oil in estuaries is yet to be determined, a number of studies have documented the impact to the fishes that reside in these areas. Field studies have documented the effects of DWH oil on resident fishes throughout the northern GoM (Fodrie \& Heck 2011), including in Louisiana (Able et al. 2015), Mississippi (Schaefer et al. 2016), and Alabama (Moody et al. 2013). Results of these studies have overwhelmingly identified few drastic population or community changes (Fodrie et al. 2014), and even some increases in catch-per-uniteffort post spill (Fodrie \& Heck 2011, Schaefer et al. 2016). Notably, very few negative impacts have been documented for resident fauna, with the exception of a short-term decline in goby biomass/density that rebounded after $1 \mathrm{yr}$ in coastal Alabama (Moody et al. 2013). These results mirror those of previous oil spills in the GoM, with constant or increasing densities and no change in community structure after oiling by smaller spills in Texas (Rozas et al. 2000) and Barataria Bay, Louisiana (Roth \& Baltz 2009).

Despite this consistent lack of effects in the field, a number of laboratory experiments have documented the negative effects of oil on fishes (Fodrie et al. 2014), with deleterious impacts ranging from genomic (Garcia et al. 2012, Whitehead et al. 2012, Dubansky et al. 2013) to morphological alterations (de Soysa et al. 2012, Incardona et al. 2013). A substantial focus of previous studies has been the effects of oiling on early developmental stages of fish, as they are more sensitive than adults. The greater sensitivity of larval fishes is related to their size and lack of development (resulting in thin membranes and poorly developed systems for detoxification) and their pelagic lifestyle, which increases the risk of oil exposure. However, oil can still have considerable negative effects on adult organisms, with documented examples of reduced foraging efficiency (Gregg et al. 1997), impaired swimming behavior (Claireaux et al. 2004), and other potential indirect effects such as shifts in diet (Brzorad \& Burger 1994) and delayed effects, such as the collapse of the Pacific herring population 4 yr after the Exxon Valdez oil spill (Thorne \& Thomas 2008).

The dichotomy in results to date, with consistent negative effects at the individual level that fail to translate to population and community levels (Fodrie et al. 2014), could be explained by a number of potential mechanisms. For example, weathered oil reaching estuaries was often patchily distributed (Michel et al. 2013) and may have been below toxic levels. Therefore, fishes may have been able to survive and continue to reproduce despite experiencing some sublethal effects. For those organisms that did succumb to oil toxicity, many marine fishes have strong compensatory responses, especially short-lived fishes with high reproductive capabilities, such that affected areas may quickly be colonized by recruits from nearby, unaffected areas (Myers et al. 1999).

To date, one undocumented aspect that may lend resiliency to estuarine fishes is behavior and the capacity of fishes to detect and avoid oil. Here, the results of a series of experiments designed to test whether $3 \mathrm{com}$ mon inhabitants of inshore GoM ecosystems demonstrate oil avoidance behavior are presented. Specifically, laboratory choice experiments were used to test: (1) whether species-specific patterns in behavior exist, and (2) avoidance patterns for unoiled versus a range of fresh and weathered oil concentrations.

\section{MATERIALS AND METHODS}

\section{Study organisms}

Gulf killifish Fundulus grandis, sheepshead minnow Cyprinodon variegatus, and sailfin molly Poe- 
cilia latipinna were selected for inclusion in this study due to their abundance and widespread distribution in coastal salt marshes, seagrass beds, mangroves, and unvegetated shallow habitats throughout the GoM. Able et al. (2015) reported F. grandis to be the most abundant catch collected in minnow traps following the DWH oil spill, with highest abundances in marsh creeks, while $C$. variegatus and $P$. latipinna were among the 5 most abundant marsh fishes, especially in marsh ponds ( $>65 \%$ of the catch) and depressions $(>37 \%)$. In addition, F. grandis is commonly used as a sentinel species and a frequent model organism in toxicology studies, along with $C$. variegatus (Able et al. 2015, Fodrie et al. 2014, Dasgupta et al. 2016, Raimondo et al. 2016). All organisms used in this study were adults collected from unoiled marshes near Louisiana Universities Marine Consortium (LUMCON) and consistent in size (total lengths: F. grandis $64-102 \mathrm{~mm}$; C. variegatus 41$60 \mathrm{~mm}$; P. latipinna 42-62 mm). All fishes were released back into the wild after the study.

\section{Experimental setup}

Oil used in the experiments was BP Surrogate Oil, obtained from the Marlin Platform near the site of the DWH drilling platform. This oil has almost identical toxicity/chemistry as that of the crude oil released during the DWH spill (Martin et al. 2015). Prior to experiments, oil was weathered by aerating it in a volumetric flask in a fume hood to $40 \%$ by weight, a weathering representative of much of the oil that came ashore (E. Overton pers. comm.). Sediment collected from unoiled areas near Lake Pontchartrain, Louisiana, was used and, when applicable, mixed homogenously with oil, placed on 1 randomized side of a 381 tank containing an airstone, and filled with 10 psu water mixed using Instant Ocean ${ }^{\mathrm{TM}}$ salt and dechlorinated tap water.

Tanks were randomly assigned oil concentrations (low, medium, or high) and weathering (unweathered or $40 \%$ weathered) such that each fish species had a choice between no oil and each unique concentration and condition of oil (no oil vs. unweathered low oil, no oil vs. unweathered medium oil, no oil vs. unweathered high oil, no oil vs. weathered low oil, no oil vs. weathered medium oil, no oil vs. weathered high oil). The concentrations of oil used in the

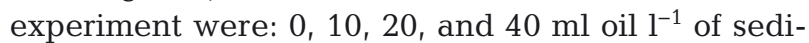
ment for the no oil and the low, medium, and high oil treatments, respectively. These concentrations span the range of oiling found in field studies (Turner et al.
$2014 \mathrm{a}, \mathrm{b}$ ) and were used in previous experimental assessments (Horel et al. 2012, Martin et al. 2015). All treatments were replicated $(\mathrm{n}=10)$, and no individual was used more than once in trials. A randomized sample of sediment was taken from each unique treatment level and analyzed for alkane and aromatic oil concentrations to verify treatments following methods described by Turner et al. $(2014 a, b)$.

During trials, 1 fish was released into the tank and allowed to acclimate for a period of $5 \mathrm{~min}$. Its movements between the 2 'habitats' (no oil vs. respective treatments) were then recorded using a GoPro digital camera (1040HD) for a period of $10 \mathrm{~min}$. These experimental periods are similar to those used in other studies of fish behavior (Gerlach et al. 2007, Paris et al. 2013, Martin 2017). The time spent on each side of the tank was documented and compared among treatments. A series of trials with no oil on either side were also conducted and indicated no preference for a particular side of the tank; these data were not included in further analyses.

\section{Statistical analyses}

A general linear model was created, using time spent in the side of the tank containing oil as a response variable and oil concentration (low, medium, high), weathering (unweathered, weathered), and species (F. grandis, C. variegatus, or P. latipinna) as factors. When significant differences were detected, a Tukey's post hoc test was performed. Comparisons of habitat preference were made by assuming a 1:1 occupancy in each habitat and testing whether the time spent on each side of the tank varied significantly using a paired $t$-test (Peterson \& Renaud 1989, Martin \& Valentine 2011). Prior to all analyses, normality and homogeneity of variance were tested and transformations were made, if necessary. Nonparametric alternatives were used if transformations failed to meet assumptions of the tests. Results were considered significant at $p<0.05$, and highly significant at $\mathrm{p}<0.01$.

\section{RESULTS}

Sediment alkane (Fig. A1 in the Appendix) and aromatic (Fig. A2) concentrations confirmed the presence of various oil compounds across treatments. Specifically, fresh oil contained total alkane concentrations of $25510,4236,3292$, and $0.856 \mu^{-1} \mathrm{~g}^{-1}$ for high, medium, low, and no oil, respectively, while 
weathered oil contained 5349, 3659, 2730, and $0.735 \mu \mathrm{g} \mathrm{g}^{-1}$, respectively. Likewise, total aromatic concentrations varied across treatments with fresh oil containing more (high: 1561, medium: 596, low: 274,

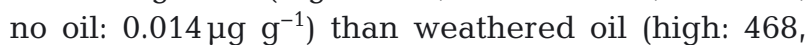
medium: 238, low: 185, no oil: $0.357 \mu \mathrm{g} \mathrm{g}^{-1}$ ).

Response of fishes to the presence of oil was consistent among the 3 species tested here (Fig. $1_{i} F_{2,162}=$ $0.60, \mathrm{p}=0.549$ ). However, avoidance behavior was significantly different among the different concentrations of oil $\left(F_{2,162}=3.97, \mathrm{p}=0.021\right)$, with medium and high concentrations usually eliciting a stronger response than low concentrations (Fig. 1). Oil weathering also had a highly significant effect $\left(F_{1,162}=\right.$ $46.37, \mathrm{p}<0.001$ ) on avoidance, with greater response to fresh oil than weathered oil. No interactive effects were detected (species $\times$ oil concentration $F_{4,162}=$ $0.66, \mathrm{p}=0.169$; species $\times$ oil weathering $F_{2,162}=2.19$, $\mathrm{p}=0.115$; oil concentration $\times$ oil weathering $F_{2,162}=$ $2.05, \mathrm{p}=0.133$; species $\times$ oil concentration $\times$ oil weathering $F_{4,162}=0.56, \mathrm{p}=0.695$ ).

Individual comparisons between time spent in oil or no oil for each choice test highlighted important differences in fish behavior. For example, weathered crude had no effect on the habitat occupancy patterns for any of the 3 fish species, with the proportion of
Table 1. Paired $t$-test statistics for each species and comparison. Low, medium, and high oil concentrations were 10, 20, and $40 \mathrm{ml} \mathrm{oil}^{-1}$ of sediment, respectively

\begin{tabular}{|lcc|}
\hline Comparison & $t$ & $\mathrm{p}$ \\
\hline Fundulus grandis & & \\
No oil vs low oil & -2.479 & 0.035 \\
No oil vs weathered low oil & 0.456 & 0.659 \\
No oil vs medium oil & -2.622 & 0.028 \\
No oil vs weathered medium oil & -0.821 & 0.433 \\
No oil vs high oil & -5.279 & 0.001 \\
No oil vs weathered high oil & 0.541 & 0.601 \\
& & \\
Poecilia latipinna & & \\
No oil vs low oil & -0.904 & 0.390 \\
No oil vs weathered low oil & 0.0163 & 0.747 \\
No oil vs medium oil & -8.152 & 0.001 \\
No oil vs weathered medium oil & -0.462 & 0.655 \\
No oil vs high oil & 2.784 & 0.002 \\
No oil vs weathered high oil & 0.817 & 0.435 \\
& & \\
Cyprinodon variegatus & & \\
No oil vs low oil & -1.836 & 0.100 \\
No oil vs weathered low oil & 1.259 & 0.240 \\
No oil vs medium oil & 2.963 & 0.001 \\
No oil vs weathered medium oil & -0.768 & 0.462 \\
No oil vs high oil & -8.001 & 0.001 \\
No oil vs weathered high oil & 0.907 & 0.388 \\
\hline
\end{tabular}

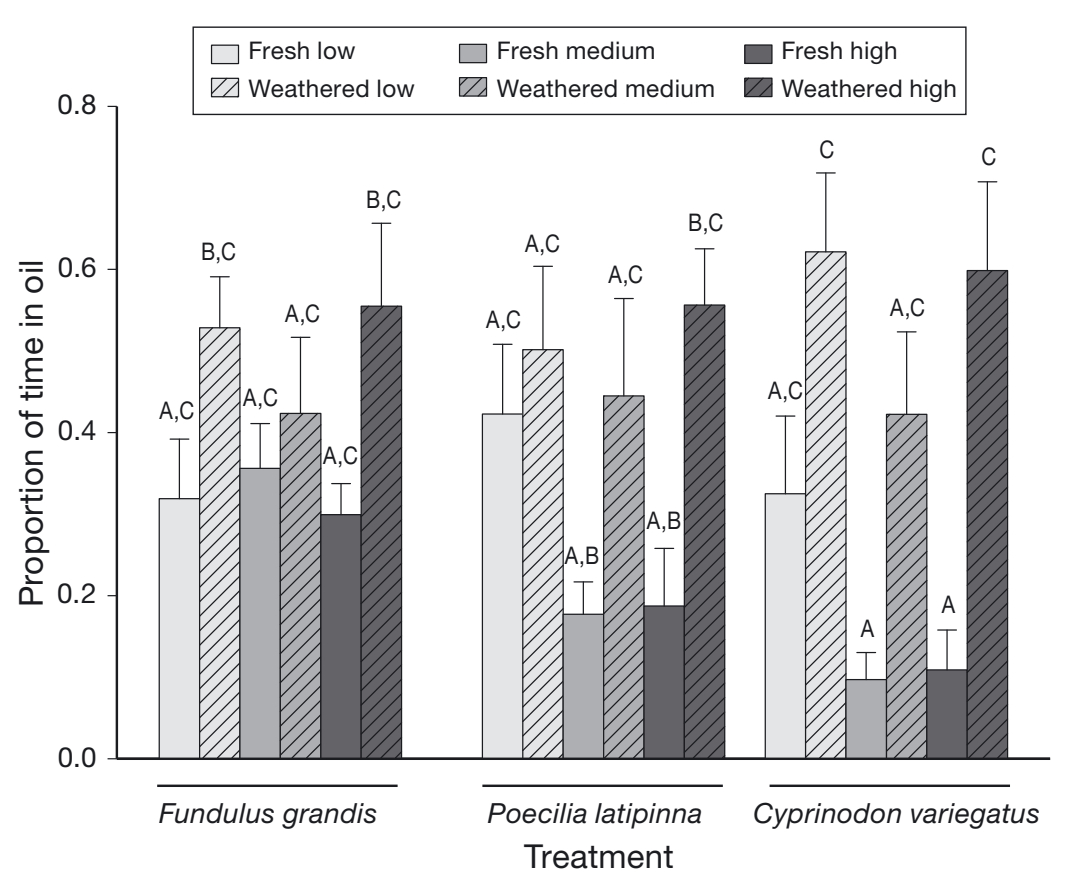

Fig. 1. Comparison of time spent in the side of the tank containing oil among fish species and oil concentrations and degree of weathering. Light grey, grey, and dark grey indicate low, medium, and high oil concentrations, respectively. Solid bars represent fresh oil; hatched bars show weathered oil. Different letters indicate statistically significant differences $(p<0.05)$ time in oil ranging from 0.4 to 0.6 (Table 1, Figs. 2-4). In contrast, higher concentrations of fresh oil elicited a very strong avoidance response from all fishes tested $(\mathrm{p}<0.001$; Table 1, Figs. 2-4). Fundulus grandis, Poecilia latipinna, and Cyprinodon variegatus all spent small amounts of time (about 30,20 , and $15 \%$, respectively) over sediments with high concentrations of fresh oil. Medium concentrations of fresh oil also elicited a highly significant, very strong response $(p<0.001)$ from P. latipinna (Table 1, Fig. 3) and C. variegatus (Table 1, Fig. 4) ( 18 and $10 \%$ of the trial duration, respectively) and a significant response $(\mathrm{p}<0.05)$ from F. grandis (Table 1, Fig. 2) ( $35 \%$ of the trial duration). The response of fishes to low concentrations of fresh oil were variable, however. F. grandis displayed significant avoidance (Table 1, Fig. 2), spending around $30 \%$ of the trial in the side of the tank containing sediment with a low concentration of fresh oil, while $C$. variegatus averaged 


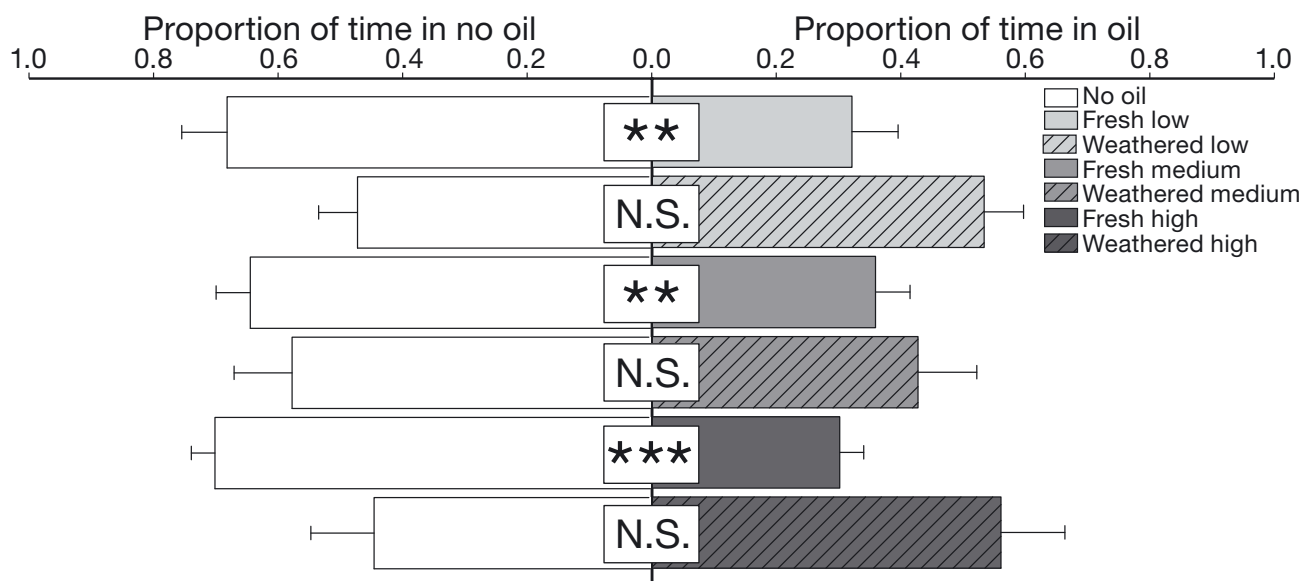

Fig. 2. Proportion of time spent in the side of the tank containing no oil (left) and oil (right) for Fundulus grandis. Light grey, grey, and dark grey indicate low, medium, and high oil concentrations, respectively. Solid bars represent fresh oil; hatched bars show weathered oil. NS: not significant, ${ }^{*} \mathrm{p}<0.10,{ }^{* *} \mathrm{p}<0.05,{ }^{* * *} \mathrm{p}<0.001$

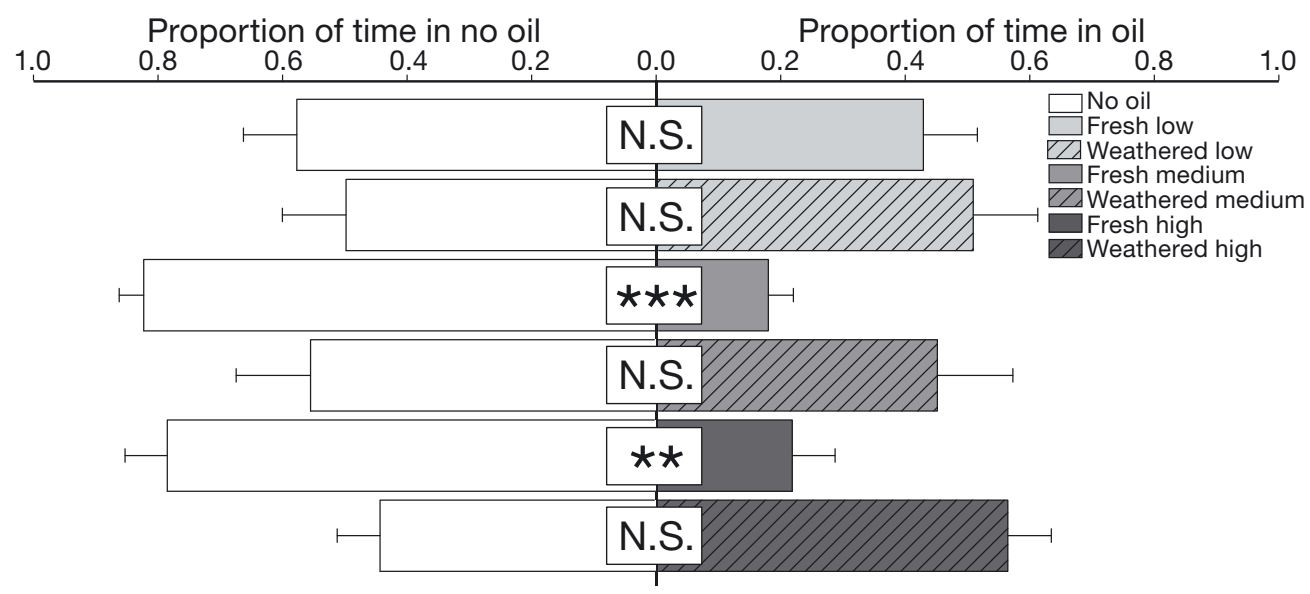

Fig. 3. As in Fig. 2, but for Poecilia latipinna

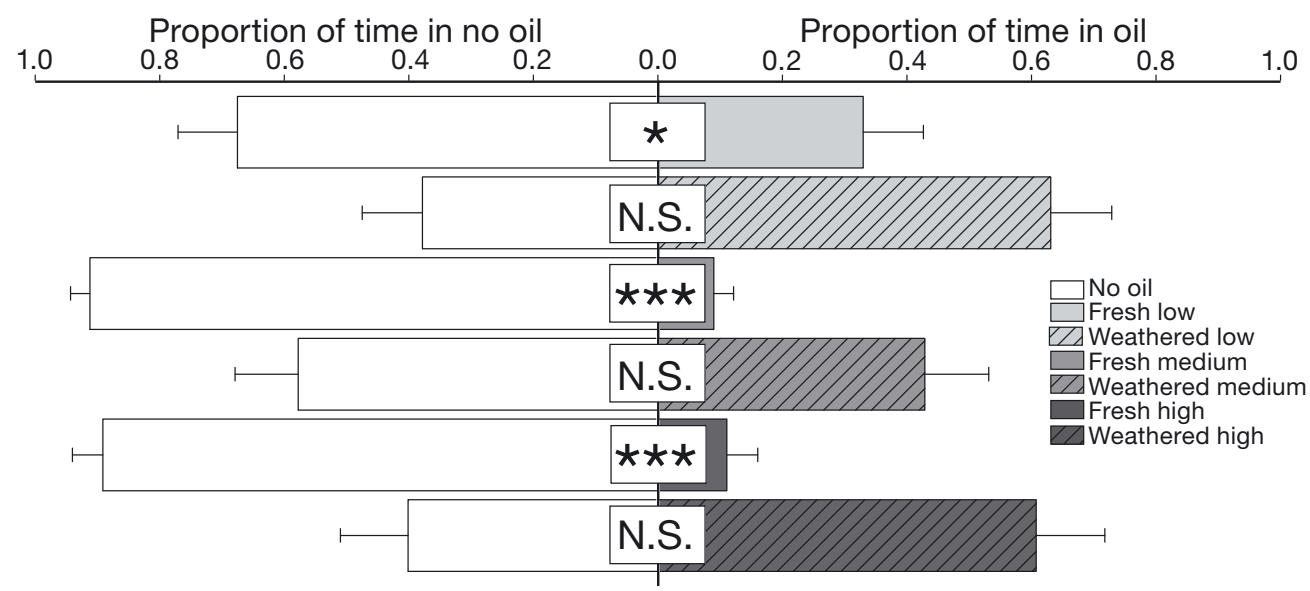

Fig. 4. As in Fig. 2, but for Cyprinodon variegatus 
$\sim 40 \%$ of the time in oil, perhaps a biologically meaningful $(\mathrm{p}<0.10)$ avoidance (Table 1, Fig. 4). P. latipinna did not exhibit a response to fresh oil at low concentrations, with over $40 \%$ of the trial duration spent in the oiled portion of the tank.

\section{DISCUSSION}

The devastating effects of the 2010 DWH disaster included loss of human and marine life, as well as negative effects on coastal ecosystems such as acceleration of marsh loss (Silliman et al. 2012). While some negative effects on fishes have been reported offshore (Murawski et al. 2014) and in laboratory studies on inshore fishes, the consequences for many coastal fishes remain uncertain. Although controlled manipulations of oil demonstrate significant negative physiological effects, surveys of communities and populations in affected areas have yet to demonstrate long-term consequences of these individual-level effects (Fodrie et al. 2014).

Results presented here demonstrate that these estuarine fishes exhibit strong aversions for fresh oil at medium and high concentrations. However, at low concentrations of fresh oil, only Fundulus grandis responded significantly. In contrast, fishes in choice trials with weathered oil did not display significant preference patterns at any concentration. Given the range of oil constituents found in nearshore ecosystems such as salt marshes (Turner et al. 2014a,b), these results highlight the need for a more detailed and ecologically relevant assessment of laboratory assays, as many controlled experiments to date only use fresh, unweathered oil to make predictions regarding the effects of oil in the field. In addition, laboratory experiments measuring physiological and morphological responses may overestimate field responses due to these experimental artifacts (but see Whitehead et al. 2012). As such, the discrepancy in studies to date could be due in part to organism avoidance of freshly oiled, and hence more toxic, sediment.

The origin of oil offshore in Louisiana allowed considerable time and opportunity for enhanced weathering and ultraviolet degradation of oil before it reached nearshore ecosystems. When oil finally arrived onshore, the more toxic chemicals (such as naphthalenes) had already precipitated, leaving the more stable, longer carbon chains that dissolve less readily into the water and are less toxic to nekton (Reddy et al. 2012, Turner et al. 2014a,b). As such, it is plausible that fish use these most toxic compounds as a cue to guide avoidance behavior. Future research should focus on isolating individual constituents of oil that may trigger the responses observed in the current study. Further, it is unclear whether skin irritation from aromatic compounds, or olfactory detection of oil drives the behavioral patterns documented here, and future research should be directed at determining the relative roles of each mechanism.

These results point to the importance of conducting oil studies at relevant concentrations and degrees of weathering. In nearshore areas, crude oil is usually highly weathered and less toxic to fishes (although it is important to note that no mortality was detected in these trials, even with fresh oil) (Reddy et al. 2012). Unweathered crude, however, may be found in coastal areas in the center, protected portion of tar balls, and bound to sediments in anoxic areas where degradation is slower (Mendelssohn et al. 2012).

Contaminants, such as petroleum hydrocarbons, have long been known to alter animal behavior (Weis et al. 2001). Oil-induced avoidance behavior has been documented in a number of aquatic organisms. At very small scales, calanoid copepods consistently alter their swimming behavior to avoid patches of water-soluble fractions of diesel oil, suggesting that behavioral capacities could minimize exposure (Seuront 2010). Likewise, acoustic recordings have confirmed that sperm whales that historically used the area near the DWH spill site relocated to a site farther away from the oiled area (Ackleh et al. 2012). Other marine mammals such as dolphins are known to avoid oil mousse (Smultea \& Würsig 1995), and have even been trained to detect oil via olfactory mechanisms (Geraci et al. 1983).

Previous studies have also documented the response of fishes to oil contamination. For example, Farr et al. (1995) manipulated concentrations of fluoranthene, a toxic polycyclic aromatic hydrocarbon, and found that fathead minnows Pimephales promelas avoided contaminated waters down to $8.6 \mu \mathrm{g} \mathrm{l}^{-1}$. Similarly, both striped bass Morone saxatilis and rainbow trout Oncorhynchus mykiss avoided effluent from a California oil refinery (Carr et al. 1990). In the marine environment, juvenile flatfishes (Moles et al. 1994) and juvenile spot Leiostomus xanthurus (Hinkle-Conn et al. 1998) avoided heavily oiled sediments, but not lightly oiled areas.

Given that the fishes included in this study did not avoid weathered crude or (in some cases) low concentrations of fresh oil, a rich field of future study includes the sublethal, indirect effects of oil on fauna. Some organisms, such as fiddler crabs and terrestrial 
arthropods, exhibited an initially negative response to oil that came ashore (McCall \& Pennings 2012). However, with less water-soluble compounds to affect organisms at higher weathering rates (Mendelssohn et al. 2012), which comprised the bulk of the oil that came ashore (Reddy et al. 2012), coupled with the lack of strong population/community responses (Fodrie et al. 2014), it is likely that fishes in affected areas were exposed to crude oil at sublethal levels.

To date, several studies have noted the sublethal consequences of oil. Field mesocosms in a range of contaminated areas found that penaeid shrimps grow more slowly in heavily oiled areas (Rozas et al. 2014). Specifically, a $60 \%$ decrease in brown shrimp Farfantepenaeus aztecus daily growth rate was observed after only $7 \mathrm{~d}$. While varying sensitivities to contamination may influence food sources (Brzorad \& Burger 1994, Thorne \& Thomas 2008), oil also reduces foraging activity. Foraging rates of darter gobies Gobionellus boleosoma were reduced by 50 to $100 \%$ in the presence of diesel-contaminated sediments, but not at low concentrations (Gregg et al. 1997). Likewise, spot exhibited decreased feeding strikes within 30 min during feeding trials in sediments contaminated with diesel fuel (Hinkle-Conn et al. 1998). A broader understanding of these sublethal effects in salt marsh ecosystems is needed to fully assess food web alterations in the wake of the DWH spill.

The results of this study contribute significantly to our understanding of estuarine fish resilience to disasters such as oil spills. Behavior likely plays a key role in fish persistence in nearshore environments such as salt marshes. However, it is noteworthy that many fishes may not exhibit such behavior and may not be as resilient to these contaminants. Marsh fishes, such as those used here, are exposed to a wide range of environmental conditions including extreme fluctuations in temperature and dissolved oxygen, and as a result may be more tolerant of stressful conditions. The fauna and flora of Louisiana have been exposed to oil for centuries through natural seeps and human exploitation. Therefore, it is possible that exposure may have been a selecting force for fishes exhibiting such behavioral responses, but future research needs to confirm this. This study establishes important baseline information regarding the behavior of fishes exposed to these contaminants, with critical implications for the continued management of coastal ecosystems.

Acknowledgements. This research was made possible by a grant from The Gulf of Mexico Research Initiative. Data are publicly available through the Gulf of Mexico
Research Initiative Information Data Cooperative (GRIIDC) at https://data.gulfresearchinitiative.org (doi:10.7266/N7 NV9G95). This manuscript was inspired and has been greatly improved through discussions with K. Able, J. Fodrie, O. Jensen, P. Lopez-Duarte, B. Roberts, E. Turner, and J. Valentine and the constructive criticisms of anonymous reviewers.

\section{LITERATURE CITED}

Able KW, López-Duarte PC, Fodrie FJ, Jensen OP and others (2015) Fish assemblages in Louisiana salt marshes: effects of the Macondo oil spill. Estuar Coast 38:1385-1398

Ackleh AS, Ioup GE, Ioup JW, Ma B and others (2012) Assessing the Deepwater Horizon oil spill impact on marine mammal population through acoustics: endangered sperm whales. J Acoust Soc Am 131:2306-2314

Baltz DM, Rakocinski C, Fleeger JW (1993) Microhabitat use by marsh-edge fishes in a Louisiana estuary. Environ Biol Fishes 36:109-126

Brzorad JN, Burger J (1994) Fish and shrimp populations in the Arthur Kill. In: Burger J (ed) Before and after an oil spill: the Arthur Kill. Rutgers University Press, New Brunswick, NJ, p 178-200

Carr RS, Barrows ME, Reichenbach NG, DeGraeve GM, Pollock TL, Fava JA, Glickman AH (1990) Investigation of preference-avoidance responses to an oil refinery effluent with striped bass and steelhead trout. Environ Toxicol Chem 9:1513-1521

* Claireaux G, Désaunay Y, Akcha F, Aupérin B and others (2004) Influence of oil exposure on the physiology and ecology of the common sole Solea solea: experimental and field approaches. Aquat Living Resour 17:335-351

* Crone TJ, Tolstoy M (2010) Magnitude of the 2010 Gulf of Mexico oil leak. Science 330:634

*Dasgupta S, Di Giulio RT, Drollette BD, Plata D, Brownawell BJ, McElroy AE (2016) Hypoxia depresses CYP1A induction and enhances DNA damage, but has minimal effects on antioxidant responses in sheepshead minnow (Cyprinodon variegatus) larvae exposed to dispersed crude oil. Aquat Toxicol 177:250-260

* de Soysa TY, Ulrich A, Friedrich T, Pite D and others (2012) Macondo crude oil from the Deepwater Horizon oil spill disrupts specific developmental processes during zebrafish embryogenesis. BMC Biol 10:40

* Dubansky B, Whitehead A, Miller JT, Rice CD, Galvez F (2013) Multitissue molecular, genomic, and developmental effects of the Deepwater Horizon oil spill on resident Gulf killifish (Fundulus grandis). Environ Sci Technol 47: 5074-5082

*Farr AJ, Chabot CC, Taylor DH (1995) Behavioral avoidance of fluoranthene by fathead minnows (Pimephales promelas). Neurotoxicol Teratol 17:265-271

*Fodrie FJ, Heck KL Jr (2011) Response of coastal fishes to the Gulf of Mexico oil disaster. PLOS ONE 6:e21609

Fodrie FJ, Able KW, Galvez F, Heck KL Jr and others (2014) Integrating organismal and population responses of estuarine fishes in Macondo spill research. Bioscience 64: 778-788

*Garcia TI, Shen Y, Crawford D, Oleksiak MF, Whitehead A, Walter RB (2012) RNA-Seq reveals complex genetic response to Deepwater Horizon oil release in Fundulus grandis. BMC Genomics 13:474

Geraci JR, St Aubin DJ, Reisman RJ (1983) Bottlenose dol- 
phins, Tursiops truncatus, can detect oil. Can J Fish Aquat Sci 40:1516-1522

Gerlach G, Atema J, Kingsford MJ, Black KP, Miller-Sims V (2007) Smelling home can prevent dispersal of reef fish larvae. Proc Natl Acad Sci USA 104:858-863

Gregg JC, Fleeger JW, Carman KR (1997) Effects of suspended, diesel-contaminated sediment on feeding rate in the darter goby, Gobionellus boleosoma (Teleostei: Gobiidae). Mar Pollut Bull 34:269-275

Hinkle-Conn C, Fleeger JW, Gregg JC, Carman KR (1998) Effects of sediment-bound polycyclic aromatic hydrocarbons on feeding behavior in juvenile spot (Leiostomus xanthurus Lacepede: Pisces). J Exp Mar Biol Ecol 227: 113-132

Horel A, Mortazavi B, Sobecky PA (2012) Responses of microbial community from northern Gulf of Mexico sandy sediments following exposure to Deepwater Horizon crude oil. Environ Toxicol Chem 31:1004-1011

Incardona JP, Swarts TL, Edmunds RC, Linbo TL and others (2013) Exxon Valdez to Deepwater Horizon: comparable toxicity of both crude oils to fish early life stages. Aquat Toxicol 142-143:303-316

Martin CW (2017) Effects of macrophyte-specific olfactory cues on fish preference patterns. Aquat Ecol 51:159-165

Martin CW, Valentine JF (2011) Impacts of a habitat-forming exotic species on estuarine structure and function: an experimental assessment of Eurasian milfoil. Estuar Coast 34:364-372

Martin CW, Hollis LO, Turner RE (2015) Effects of oil-contaminated sediments on submerged vegetation: an experimental assessment of Ruppia maritima. PLOS ONE 10: e0138797

McCall BD, Pennings SC (2012) Disturbance and recovery of salt marsh arthropod communities following BP Deepwater Horizon oil spill. PLOS ONE 7:e32735

McCann M, Able K, Fodrie J, Jensen O and others (in press) Key taxa in food web responses to stressors: the Deepwater Horizon oil spill. Front Ecol Environ

Mendelssohn IA, Andersen GL, Baltz DM, Caffey RH and others (2012) Oil impacts on coastal wetlands: implications for the Mississippi River Delta ecosystem after the Deepwater Horizon oil spill. Bioscience 62:562-574

Michel J, Owens EH, Zengel S, Graham A and others (2013) Extent and degree of shoreline oiling: Deepwater Horizon oil spill, Gulf of Mexico, USA. PLOS ONE 8:e65087

Moles A, Rice S, Norcross BL (1994) Non-avoidance of hydrocarbon laden sediments by juvenile flatfishes. Neth J Sea Res 32:361-367

Moody RM, Cebrian J, Heck KL Jr (2013) Interannual recruitment dynamics for resident and transient marsh species: evidence for a lack of impact by the Macondo oil spill. PLOS ONE 8:e58376

Murawski SA, Hogarth WT, Peebles EB, Barbeiri L (2014) Prevalence of external skin lesions and polycyclic aromatic hydrocarbon concentrations in Gulf of Mexico fishes, post-Deepwater Horizon. Trans Am Fish Soc 143: 1084-1097

Myers RA, Bowen KG, Barrowman NJ (1999) Maximum reproductive rate of fish at low population sizes. Can J Fish Aquat Sci 56:2404-2419

Paris CB, Atema J, Irisson JO, Kingsford M, Gerlach G, Guigand CM (2013) Reef odor: a wake up call for navigation in reef fish larvae. PLOS ONE 8:e72808
Peterson CH, Renaud PE (1989) Analysis of feeding preference experiments. Oecologia 80:82-86

* Peterson GW, Turner RE (1994) The value of salt marsh edge vs interior as a habitat for fish and decapod crustaceans in a Louisiana tidal marsh. Estuaries 17:235-262

* Pezeshki SR, DeLaune RD (2015) United States Gulf of Mexico coastal marsh vegetation responses and sensitivities to oil spill: a review. Environments 2:586-607

Raimondo S, Hemmer BL, Lilavois CR, Krzykwa J, Almario A, Awkerman JA, Barron MG (2016) Effects of Louisiana crude oil on the sheepshead minnow (Cyprinodon variegatus) during a life-cycle exposure to laboratory oiled sediment. Environ Toxicol 31:1627-1639

* Reddy CM, Arey JS, Seewald JS, Sylva SP and others (2012) Composition and fate of gas and oil released to the water column during the Deepwater Horizon oil spill. Proc Natl Acad Sci USA 109:20229-20234

Roth AMF, Baltz DM (2009) Short-term effects of an oil spill on marsh-edge fishes and decapod crustaceans. Estuar Coast 32:565-572

Kozas LP, Minello TJ, Henry CB (2000) An assessment of potential oil spill damage to salt marsh habitats and fishery resources in Galveston Bay, Texas. Mar Pollut Bull 40:1148-1160

Rozas LP, Martin CW, Valentine JF (2013) Effects of reduced hydrological connectivity on the nursery use of shallow estuarine habitats within a river delta. Mar Ecol Prog Ser 492:9-20

Rozas LP, Minello TJ, Miles MS (2014) Effect of Deepwater Horizon oil on growth rates of juvenile penaeid shrimps. Estuar Coast 37:1403-1414

Schaefer J, Frazier N, Barr J (2016) Dynamics of near-coastal fish assemblages following the Deepwater Horizon oil spill in the northern Gulf of Mexico. Trans Am Fish Soc 145:108-119

* Seuront L (2010) Zooplankton avoidance behaviour as a response to point sources of hydrocarbon-contaminated water. Mar Freshw Res 61:263-270

Silliman BR, Van De Koppel J, McCoy MW, Diller J and others (2012) Degradation and resilience in Louisiana salt marshes after the BP-Deepwater Horizon oil spill. Proc Natl Acad Sci USA 109:11234-11239

Smultea MA, Würsig B (1995) Behavioral reactions of bottlenose dolphins to the Mega Borg oil spill, Gulf of Mexico 1990. Aquat Mamm 21:171-181

*Thorne RE, Thomas GL (2008) Herring and the 'Exxon Valdez' oil spill: an investigation into historical data conflicts. ICES J Mar Sci 65:44-50

Turner RE, Overton EB, Meyer BM, Miles MS and others (2014a) Distribution and recovery trajectory of Macondo (Mississippi Canyon 252) oil in Louisiana coastal wetlands. Mar Pollut Bull 87:57-67

* Turner RE, Overton EB, Meyer BM, Miles MS, Hooper-Bui L (2014b) Changes in the concentration and relative abundance of alkanes and PAHs from the Deepwater Horizon oiling of coastal marshes. Mar Pollut Bull 86:291-297

WWeis JS, Smith G, Zhou T, Santiago-Bass C, Weis P (2001) Effects of contaminants on behavior: biochemical mechanisms and ecological consequences. Bioscience 51:209-217

* Whitehead A, Dubansky B, Bodinier C, Garcia TI and others (2012) Genomic and physiological footprint of the Deepwater Horizon oil spill on resident marsh fishes. Proc Natl Acad Sci USA 109:20298-20302 
Appendix. Sediment oil concentrations used in behavior experiments
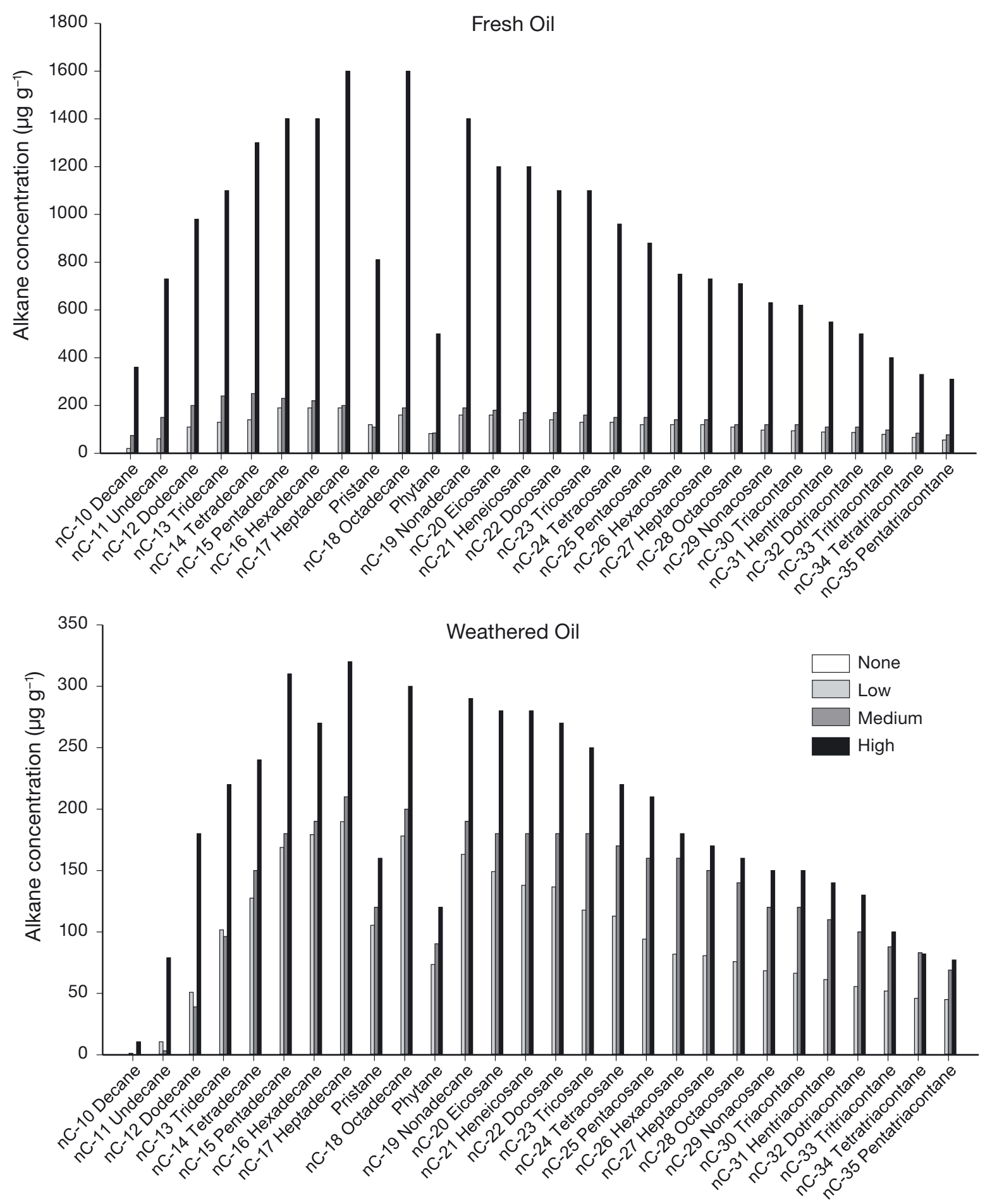

Fig. A1. Alkanes measured in sediment of each treatment for fresh and weathered oil trials (where low, medium, and high oil concentrations were 10,20 , and $40 \mathrm{ml}$ oil $\mathrm{l}^{-1}$ of sediment) 

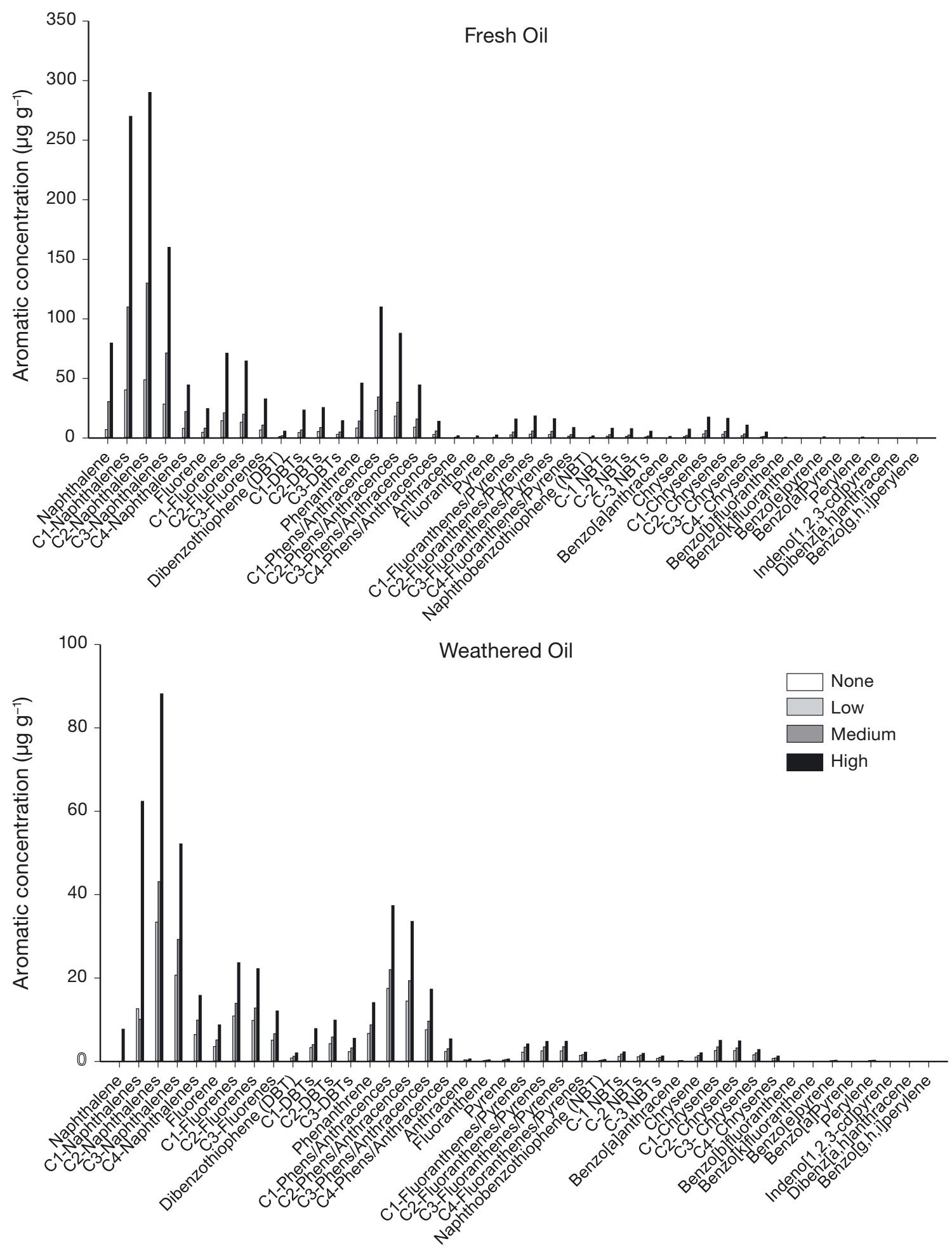

Fig. A2. Aromatics measured in sediment of each treatment for fresh and weathered oil trials (where low, medium, and high oil concentrations were 10,20 , and $40 \mathrm{ml}$ oil $\mathrm{l}^{-1}$ of sediment)

Editorial responsibility: Kenneth Heck Jr., Dauphin Island, Alabama, USA
Submitted: August 22, 2016; Accepted: February 2, 2017

Proofs received from author(s): March 6, 2017 